\title{
Reverse Transcriptase Inhibitor
}

National Cancer Institute

\section{Source}

National Cancer Institute. Reverse Transcriptase Inhibitor. NCI Thesaurus. Code C1589.

Any substance that inhibits the activity of viral reverse transcriptase, an RNA-dependent

DNA polymerase that transcribes viral RNA into DNA during virus replication. 